\section{Global Management Accounting Principles: Relationship between Management Practices and the Performance of Brazilian Companies}

Ingrid Laís de Sena Costa ${ }^{1,2}$

Wenner Glaucio Lopes Lucena ${ }^{2}$

\section{Abstract}

Purpose - Economic changes related to organizational structures and new business models require a new positioning of management accounting. The Global Management Accounting Principles (GMAP), as a guide to good practice, play the role of assisting organizations in creating better frameworks to support their decisions. The objective of this research is to analyze the relationship between the GMAP and the performance of Brazilian companies, from both an operational and an economic perspective.

Design/methodology/approach - The final sample comprised 342 companies listed on the B3 (Brasil, Bolsa, Balcão) exchange, from 2010 to 2016. The methodology used to answer the research problem consisted of constructing an index of compliance with the recommendations proposed by the GMAP and observing the impacts of good management accounting practices on organizational performance, which was estimated according to operational and economic aspects.

Findings - It was observed that the adopted management practices positively affect market performance and future growth expectations. This is already presumed by the CGMA proposal and the management literature, since management practices are routines incorporated into the organizational identity of companies and are reflected in better long-term results.

Research Practical \& Social implications - Considering the results obtained, the study contributes to the proposal presented by the CGMA, by reinforcing the role that management accounting plays in companies' decision making, and how it is a relevant element for the future performance of organizations. In addition, it contributes to the market by presenting a structure focused specifically on controlling and management decisions, to assist in choosing tools that have a positive impact on results.

Keywords - Global Management Accounting Principles; Performance; Organizational Performance; Brazilian Companies.

1.Federal University of Tocantins, Accounting Department, Palmas, Brazil

2. Federal University of Paraíba, Finance and Accounting Department, João Pessoa, Brazil

How to cite:

Costa, I. L. S., Lucena, W. G. L. (2021). GLOBAL MANAGEMENT ACCOUNTING PRINCIPLES: Relationship between Management Practices and the Performance of Brazilian Companies. Revista Brasileira de Gestão de Negócios, 23(3), p.503-518.
Received on:

02/19/2019

Approved on:

02/05/2021

Responsible Editor:

Prof. Dr. Ilídio Lopes

Evaluation process:

Double Blind Review

Reviewers:

Nelson Hein; Maria Margarete

Baccin Brizolla

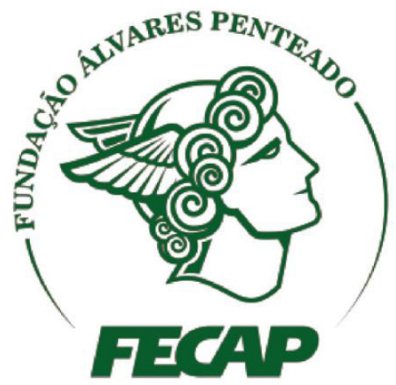

Revista Brasileira de Gestáo de Negócios

https://doi.org/10.7819/rbgn.v.23i3.4112 


\section{Introduction}

Managerial accounting is one of the main sources of data and information that assists in the decision making of organizations. It is important to note that its role in companies' development is not only limited to costing or setting sales prices, but also covers developing strategies that promote competitive advantages, higher performance, and organizational continuity in the market. Management accounting needs to be reinvented and adapt to changes inside and outside organizations, such as new technologies, business restructuring operations, and new business models, such as e-commerce (Kaplan, 1984; Lima, Espejo, Pereira, \& Frezatti, 2011).

Given the increased competitiveness of the market, as well as the growing number of competitors, companies should look for alternatives that allow them to continue growing. Proper company management in terms of planning and operational control procedures contributes to continuity (Souza, Lisboa, \& Rocha, 2004). According to Feldmann, Jacomossi, Barrichello, and Morano (2019), improved organizational productivity is mainly due to the implementation of innovation along with best management practices.

From the point of view of investors and managers, management accounting, through the development of strategic management, must seek alternatives that increase accountability and maximize value creation. There are a number of bodies that focus on management professionals, all of which issue recommendations regarding strategies that can be adopted and reflect the expectations of investors and shareholders (Chartered Global Management Accountant [CGMA], 2016; Frezatti, Aguiar, \& Guerreiro, 2007).

These professional bodies include the Chartered Institute of Management Accountants (CIMA) and the American Institute of Certified Public Accountants (AICPA), which to discuss management accounting formed a joint venture to create the Chartered Global Management Accountant (CGMA $^{\circ}$ ) designation. This, in turn, uses a structure called Global Management Accounting Principles (GMAP), which are guides to good management practices and whose objective is to lead organizational management to robust business performance.

Organizational performance refers to the ability to implement effective strategies to achieve institutional objectives and obtain real results. Some variables that contribute to organizational success are: (a) the business model, which is seen as a way to ensure financial viability and value creation for all involved; (b) effective leadership, so that everyone in the organization seeks to achieve its goals; and (c) the organizational culture, so that the environment provides the conditions for decisions to be taken in order to increase productivity and organizational growth (Almatrooshi, Singh, \& Farouk, 2016; Petrini, Scherer, \& Back, 2016).

Regarding the impacts on an organization's performance, the GMAP can affect the company both operationally, considering that they seek to guide the use of more appropriate management practices that reduce costs, waste, and risks and help organizational relationships, as well as financially, through strategies that help create value for the organization. In this regard, the main issues raised are: sustainable waste reduction, investment in innovation, maximizing net present value and the correct allocation of resources, as well as policies that contribute to the creation of future value for stakeholders (CGMA, 2016).

According to the CGMA (2016), the adoption of the GMAP by companies enables greater management efficiency and effectiveness, especially with regard to providing information that will support decision making. The principles cover a set of good management practices that seek to improve performance, both in the short term, through cost and waste reduction, and in the long term, by strengthening organizational ties and partnerships that promote business continuity and growth, but which are mainly focused on creating value for the members that make up the organization (where actions should be recommended because of their value and not their costs). That is, the GMAP can influence performance both operationally through cost reductions and better resource management, as well as economically by means of value creation through stakeholder relationships and strengthening corporate reputation.

Given that one of the pillars of the GMAP is to assist management in achieving better performance, but also in order to investigate the new discussions raised by the CGMA, the research problem focuses on the following question: What is the influence of the Global Management Accounting Principles on the performance of Brazilian listed companies?

The research on measuring performance has examined several aspects, including managerial and financial. The concern with the performance and value creation of companies underlines the importance of taking appropriate decisions that seek to improve organizational 
performance. This means it is important to study how the management practices adopted by companies impact on performance. This study seeks to contribute to the literature on management accounting by verifying how the use of good controllership practices - following the guidelines of the GMAP - can impact the economic and financial performance and value creation of Brazilian companies.

\section{Literature Review}

\section{I Global Management Accounting Principles - GMAP}

The GMAP were created in order to assist in the mediation of company business. Management accounting is at the center of decision making and quality and relevant information helps to generate value for the company. The principles reflect the beliefs of managers, academics, and other professionals.

The CGMA seeks to provide the basis for good organizational management and considers elements such as competent people, clear principles, well-managed performance, and robust practices (CGMA, 2016). These favor greater operational efficiency and support greater company competitiveness over time.

Regarding the role of people in the process, their integration and commitment within an organization is fundamental, especially in the managerial aspect. In line with this, Almatrooshi, Singh, and Farouk (2016) argue that the performance of any organization depends to a large extent on its leaders' ability to implement strategies, as well as their ability to manage other employees of the organizations and integrate them into the company's goals and projects. Examples of measures that consider people's participation for organizational success are Japanese management philosophies such as the Kyocera approach, which focuses on a holistic view of management processes developed by Kazuo Inamori (Takeda \& Boyns, 2014).

The principles discussed here cover four elements of management accounting in organizations: (a) communication, focused on how communication can influence organizational structure; (b) relevance, in terms of providing relevant information to decision makers; (c) value, in which actions should be geared towards creating and protecting the organization's value; and finally, (d) trust, which concerns trust in the stewardship.
Regarding performance, management accounting involves the adoption of measures and strategies by management that can assist in the growth of the organization, creating value not only in the short term but, mainly, in the long-term (CGMA, 2016).

These four principles presented by the CGMA will have direct impacts on various company activities, such as cost management, external reporting, financial strategies, resource and risk management, internal audits, budgeting, tax management, project management, investment assessments, price formation, internal controls, cash management, and adherence to the rules (Borker, 2016b; CGMA, 2016). Thus, the implications relate to the strategic, tactical, and operational functions of the organization that result in value creation, sustainability, and greater responsibility towards its stakeholders.

Generally speaking, the structure proposed by the CGMA is a way of guiding organizations towards a holistic view of management. It promotes good management practices that can protect and guarantee value for everyone who is part of the organization, ranging from employees at the operational level, by providing favorable working conditions focused on sustainability and the integration of all, to top-level decision makers, by providing an informational structure that supports organizational decisions.

From this perspective, the structure proposed by the principles is in line with institutional theory, since, according to this theory, the institution rather than the decision-making individual is seen as the main object of analysis. This is similar to what is proposed by the CGMA, through the GMAP, which seek to develop management through the integration of all, focusing on the creation of value for all involved (CGMA, 2016; Guerreiro, Frezatti, Lopes, \& Pereira, 2005; Yazdifar \& Tsamenyi, 2005).

Historical institutionalism sees an institution as a form of social coherence imposed on a group of individuals through routines of thoughts and/or actions that are established (Burns \& Scapens, 2000). The GMAP are a way to institutionalize management accounting, by connecting concepts, routines, and habits that should be observed by organizations.

In this sense, the perspective of institutional theory is the most appropriate intellectual framework for understanding management accounting practices, in which the management system can be seen as an important organizational routine (Scapens, 1994). Thus, as a set of good management accounting practices recommended 
to organizations, the GMAP would lie within the scope of this theory, which integrates all individuals to act in favor of organizational objectives, based on improvements in organizational communication and the production of relevant information, which helps and optimizes the management decision-making process.

Regarding the scientific context, there are still few studies on this perspective, but the few that do exist (Borker, 2016a; Masztalerz, 2014) have sought to focus on the theoretical discourses inherent to this structure, as well as the acceptability of such observations. This initial discussion is important for the growth and recognition of the proposed document. On the other hand, it leaves a lot of room for more research to be developed on this topic, especially research examining possible impacts on the organization, in terms of its performance, organizational relationships, reporting, value, and image.

\subsection{Performance evaluation}

In order to succeed, companies need to make decisions that support high organizational performance. The advance of globalization and fierce competitiveness have led to the search for tools that aid in management and in devising strategies by showing the actual operating and economic-financial situation of the company.

The search for modern management accounting skills, competencies, performance management, and practices is directly related to the GMAP. These provide an indication of how good the current framework is, given the needs of the organization. In addition, the principles can be used to identify potential gaps and find ways to overcome them, whether they involve failures in management, technological deficiencies, or a lack of information (CGMA, 2016).

The performance measurement process is a complex task. It includes performance measures that reflect the economic and financial reality and viability of each activity developed, whether alone or jointly. It also involves the search for options to ensure company growth and continuity (Bomfim \& Callado, 2016a).

Measuring an organization's performance may encompass both operational performance by identifying the effectiveness of management strategies related to the operational process, as well as financial performance, which involves evaluating the financial strategies adopted. Another element that can also be observed in relation to performance is value creation, generated based on strategic decisions adopted by the company's management.
According to Konsta and Plorimatou (2012), for an entity to be able to measure its performance and manage its daily business and resources, it must implement strategies that provide the most appropriate direction in order to improve its economic and financial performance. Here, it is important to observe the guidelines provided by the GMAP.

Depending on the evaluation that is intended, there are different classifications of performance assessment indicators that can be used. These indicators can be classified as financial, non-financial, and economic (value-creation measures) (Ittner \& Larcker, 1998; Ittner, Larcker, \& Rajan, 1997).

For the purpose of this research, we seek to measure the operational and economic performance of Brazilian organizations. For this, we will use the return on assets (ROA) indicator, which measures the profitability generated by all of the organization's assets (resources). In other words, it expresses the returns generated by the venture operationally. This metric is commonly used to measure an organization's economic and financial performance. Studies such as those by Sheikh and Wang (2013) and Bomfim and Callado (2016a) have already used this indicator.

To measure economic performance, which encompasses the market's perception using more complete measures, based on the concept of economic profit and the measurement of value creation proposed by corporate finance (Assaf, 2014), we used market-to-book, which captures information that indicates market expectations for future returns. These are often not captured by traditional measures (Pontiff \& Schall, 1998).

\subsection{Development of research hypotheses}

Whereas the main objective of the proposal presented by the CGMA is value creation for all stakeholders, we expect the management practices advocated by this structure to impact all organizational processes, providing relevant and understandable information to all users and enabling greater performance (CGMA, 2016; Masztalerz, 2016).

Managerial mechanisms can impact organizational performance as well as value creation. Management practices, especially those aimed at the sustainable development of companies, have been pointed out as one of the main generators of value for organizations, for example by seeking risk reductions and increasing innovation in processes and profitability (Zhu \& Sarkis, 2004).

Innovation inside an organization can be seen as the way the company demonstrates that it is willing to operate in the market and seeks to ensure its continued existence. Innovation 
influences several organizational paradigms, including risk, direction, and self-definition in the long term, and even the way the company communicates its future decisions (CGMA, 2016; Frezatti, Bido, Cruz, \& Machado, 2015; Simons, 1995). The way entities develop and manage the innovation process is important to their world view, prospects for success, and how they will be seen by the market.

This research aims to verify the relationship between the GMAP and company performance. This performance will be considered from two perspectives: the first is more operational and seeks to verify the performance obtained through the activities developed by the organization; the second focuses on market perception, by also including factors that are external to the organization when verifying performance.

Based on theoretical and conceptual discussions above, the following hypotheses are proposed:

H1: Companies with greater compliance with the GMAP recommendations have higher operating performance.

H2: Companies with greater compliance with the GMAP recommendations show greater value creation.

\section{Methodological Procedures}

The research is classified as descriptive regarding its objectives, as bibliographic and documentary regarding the procedures, and quantitative regarding the analysis and treatment of the data. The population of this study comprises the Brazilian companies listed on the Brasil, Bolsa, Balcão (B3) exchange, from 2010 to 2016 . The sample initially contained 414 companies, but due to a lack of necessary data some were excluded, resulting in a final sample of 342 companies that had available data for the period.

The data were collected from the following documents provided by the companies: standardized financial statements, sustainability reports, reference forms, as well as documents made available to the Brazilian Securities Commission and information contained on the companies' websites. These were used to compose the management information related to the GMAP. Regarding the companies' economic and financial information, the data were collected from the Thomson Reuters Eikon ${ }^{\mathrm{TM}}$ database.

\section{I Composition of the GMAP observation index}

In accordance with the GMAP proposed by the CGMA, companies should disclose certain management practices and information, such as strategies, business models, performance measures, and stakeholder relationship programs. Based on this management information disclosed in the various company reports, an index of GMAP compliance was created for the companies. This was prepared based on a checklist of information provided by the companies, in which each item that the company discloses is assigned a value of 1 (one), and in the case of non-disclosure, a value of 0 (zero) is assigned. The checklist consists of the following information shown in Table 1:

Based on the information obtained through this checklist, a content analysis of the reports was performed and, subsequently, a Management Principles Observation Index (MPOI) was elaborated. This considered the sum of information disclosed by the company divided by the total information that should have been disclosed.

MPOI $=\sum_{i=1}^{n} x i / \sum_{j=1}^{m} x j$

In which:

$x i$ : total items disclosed by the company (which were assigned the value " 1 "); and

$x j$ : total items that should have been disclosed by the company.

Besides this composition, the index was also calculated in a weighted way, so that all principles had the same weight. According to the CGMA structure, all principles have the same importance for the management of companies; in other words, there is no one principle that is more important than another. Since there is not the same number of items for each principle in the assembled index structure, the weighting for each principle corresponding to $25 \%$ of the final index composition was used, as shown in the following equation:

$$
\text { MPOIWEIGHT } \left.=\left[\left(\sum_{i=1}^{n}{ }_{i=1}^{x i p i} / \sum_{i=1}^{n}{ }^{p i}\right)+\ldots+\left(\sum_{i=1}^{n} x_{i=1} p k / \sum_{i=1}^{n} p k\right)\right]\right] \sum_{j=1}^{m}{ }^{x j}
$$

In which:

$x i$ : total items disclosed by the company (which were assigned the value " 1 "); and $x j$ : total items that should have been disclosed by the company; $p i$ : the weight of each group of principles.

Considering that each index variable contains idiosyncratic components that are not related to management accounting principles, it was necessary to search for a common component that represents the GMAP. Thus, the 
Table 1

\section{Checklist of GMAP Information}

\begin{tabular}{|c|c|c|}
\hline Items & Disclosed managerial information & Collected from \\
\hline & Principle 1 - Communication provides influential insight & \\
\hline 1 & They present information arranged in a way that serves all parts of the company. & All \\
\hline 2 & They present and explain the company's strategy. & All \\
\hline 3 & They present and explain the company's business model. & All \\
\hline 4 & They present and explain the company's performance. & SFS \\
\hline 5 & They present and explain the company's strategic goals. & All \\
\hline 6 & $\begin{array}{l}\text { They present information for users such as employees, customers, suppliers, business partners, local } \\
\text { communities, legislators and regulators. }\end{array}$ & All \\
\hline 7 & Report within the required deadline. & CVM, B3 \\
\hline 8 & $\begin{array}{l}\text { They use various communication channels (print, digital, social, and mobile media). } \\
\text { Principle } 2 \text { - Information is relevant }\end{array}$ & SN, website \\
\hline 9 & $\begin{array}{l}\text { They present reports containing information on governance, business models, strategies, and } \\
\text { performance. }\end{array}$ & All \\
\hline 10 & They present information that supports resource management and organizational relationships. & All \\
\hline 11 & $\begin{array}{l}\text { They present trend structures over time (they construct a timeline with past, present, and future } \\
\text { information). }\end{array}$ & All \\
\hline 12 & $\begin{array}{l}\text { They present information that meets the current accounting standards (accounting pronouncements). } \\
\text { Principle } 3 \text { - Impact on value is analyzed }\end{array}$ & SFS \\
\hline 13 & They present information about risk management. & SFS \\
\hline 14 & $\begin{array}{l}\text { They have an impact on the economy, society, and the environment. } \\
\text { Principle } \mathbf{4} \text { - Stewardship builds trust }\end{array}$ & All \\
\hline 15 & They present the practices used to elaborate the financial statements. & SFS \\
\hline 16 & They present information on internal control practices. & $\mathrm{RF}$ \\
\hline 17 & They present information regarding audit procedures. & RF \\
\hline 18 & They address the regulations and governance standards. & SFS, RF \\
\hline
\end{tabular}

Notes. CVM - Comissão de Valores Mobiliários (Brazilian Securities Commission); B3 - Brasil, Bolsa, Balcão; SN - Social Networks; SFS - Standardized Financial Statements; RF - Reference Form.

Source: Own elaboration, based on "Princípios globais de contabilidade gerencial: contabilidade gerencial eficaz: melhorando as decisões e construindo organizações de sucesso” by the CGMA (2016).

multivariate principal component analysis (PCA) technique was used, which aims to transform a set of correlated variables into a smaller set of independent ones, called principal components. This aims to reduce and eliminate overlaps, providing the set of independent linear combinations that show the most representative part of the information present in the original variables (Maroco, 2003).

\subsection{Performance measurement}

\subsection{Financial-economic performance indicators}

The performance of the companies was verified by means of accounting indicators that capture firms' operational performance. Given that managerial accounting can help in several areas of the companies, in both operational activities as well as in financial areas, it is necessary to choose an
Table 2

\section{Description of performance variables}

\begin{tabular}{lll}
\hline \multicolumn{1}{c}{ Variables } & \multicolumn{1}{c}{ Description } & \multicolumn{1}{c}{ Font } \\
\hline Return on & Operating Profit / & (Sheikh; Wang, 2013; \\
Assets (ROA) & Total Assets & Bomfim; Callado, 2016a) \\
Market-to- & Market Value / & (Sheikh; Wang, 2013) \\
Book (MtB) & Equity Value (EV) & \\
\hline
\end{tabular}

indicator that is capable of capturing both operational and financial organizational performance. In this case, return on assets would be an adequate measure.

In order to capture the organizations' value creation, it is necessary to add market perception to the accounting measures. For this, the measure chosen to capture company value creation is the market-to-book ratio, since it represents the growth that the market expects for the companies. These are shown in Table 2: 
Table 3

\section{Description of control variables}

\begin{tabular}{llcl}
\hline \multicolumn{1}{c}{ Variables } & \multicolumn{1}{c}{ Description } & Sign expected & \multicolumn{1}{c}{ Font } \\
\hline Company Size (Size) & Log of Total Assets & $(+)$ & $\begin{array}{l}\text { (Zhu \& Sarkis, 2004; Bomfim \& } \\
\text { Callado 2016b) } \\
\text { Leverage (LEV) }\end{array}$ \\
$\begin{array}{ll}\text { Total Liabilities / Total Assets } \\
\begin{array}{l}\text { Internationalization } \\
\text { (INTER) }\end{array}\end{array}$ & $\begin{array}{l}\text { If the companies issue ADRs they will be assigned } \\
\text { the value of 1 (one), otherwise a 0 value (zero) will } \\
\text { be assigned }\end{array}$ & $(+)$ & $\begin{array}{l}\text { Montezano, 2016) } \\
\text { (Andrade \& Galina, 2013) }\end{array}$ \\
Change in revenues from period t-1 to t & & $(+)$ & (Cao \& Montezano, 2016) \\
\hline
\end{tabular}

\subsubsection{Control variables}

Based on previous studies of this theme, some control variables were selected, as shown in Table 3:

a) Company size: According to Bomfim and Callado (2016b) and Zhu and Sarkis (2004), a positive relationship with performance is expected, that is, the larger the company, the greater its performance.

b)Leverage: The level of indebtedness is expected to have a negative relationship with company performance, since the higher the indebtedness, the greater the economic risk and, consequently, the higher the cost of equity, causing a decrease in performance. This variable has been used in several studies, such as those by Cao and Montezano (2016) and Sheikh and Wang (2013).

c) Internationalization: Companies that present characteristics of internationalization are expected to have higher performance, since they operate in other markets and have greater opportunities for growth. This provides a greater competitive advantage, since their presence in other markets can lead to higher returns (Andrade \& Galina, 2013).

d)Growth: As with previous measures, the company's growth rate changes according to changes in the organization's operating strategies or decisions, which directly affects its organizational performance (Cao \& Montezano, 2016).

\subsection{Econometric model}

In order to solve the research problem, we decided to perform some econometric tests in order to evaluate the relationships amongst the variables, as well as the statistical significance amongst them. The econometric model is used to analyze the relationship between the GMAP management practices disclosed and the performance of Brazilian organizations. In this regard, the relationship between the variables was analyzed using regression models, as described by the following equations:

Model for estimating the determinants of operational performance:

$R O A_{i t}=\beta_{0}+\beta_{1} M P O I_{i t}+\beta_{2} S I Z E_{i t}+\beta_{3} L E V_{i t}+\beta_{4} G_{i t}+\beta_{5} I N T E R_{i t}+\varepsilon_{i t}$

Model for estimating the determinants of value creation:

$M t B_{i t}=\beta_{0}+\beta_{1} M P O I_{i t}+\beta_{2} S I Z E_{i t}+\beta_{3} L E V_{i t}+\beta_{4} G_{i t}+\beta_{5} I N T E R_{i t}+\varepsilon_{i t}$

In which:

MPOI $I_{i t}$ Management Principles Observation Index. The index was measured in three ways: by means of an arithmetic mean, as a weighted index, and as an index calculated using PCA.

\section{Analysis and Discussion of the Results}

\section{I Descriptive analysis of the Global Management Accounting Principles index and company performance}

The management accounting principles index was based on 18 variables that seek to represent the four principles foreseen in the CGMA literature. A variety of techniques were used to define the index. It was initially calculated according to the ratio between the questions answered by the companies and the total number of questions observed. Second, it was calculated by means 


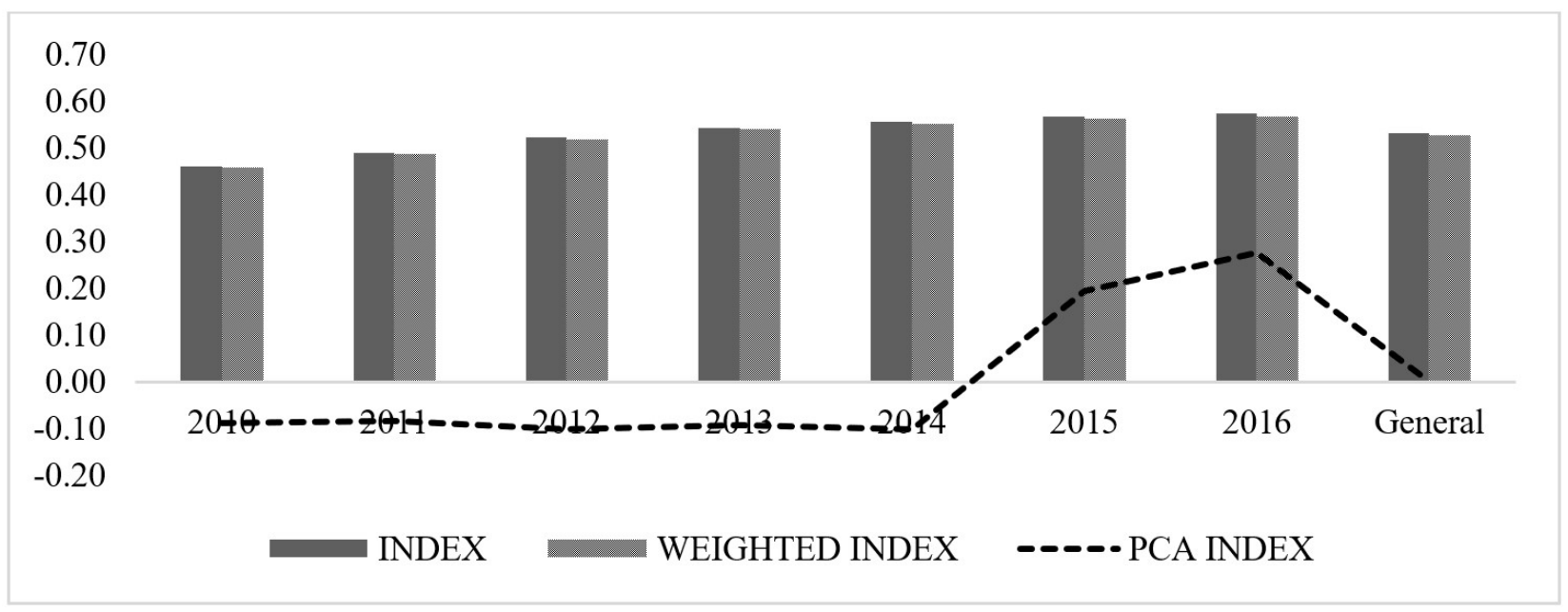

Figure 1. Means of the GMAP indexes (2010 - 2016)

of a weighted proportion for each principle, so that all have the same weight. Finally, the PCA multivariate exploratory analysis technique was used.

After the indexes were constructed, it was possible to observe their behavior in each year, as shown in Figure 1. Note that for the three compositions there is a growing percentage trend for the indexes. More specifically, in the index measured using PCA, there were much more significant oscillations in the last three periods, which is in accordance with the expected effect of the GMAP.

It is important to highlight that the index captured management accounting practices according to what is recommended by the GMAP, at a level of 53\% for the analyzed period, reaching a maximum percentage of $57 \%$ in 2016 . This means that companies are still afraid to disclose managerial information in their reports. This result is important because such information can help the various stakeholders in their decisions. On the other hand, it may be an indication of the companies' attempts to hide manager inefficiency or to suppress information as a barrier for new competitors (Aillón, Silva, Pinzan, \& Wuerges, 2013).

The data analysis used a final sample of 342 companies listed on the $\mathrm{B} 3$ exchange in the period from 2010 to 2016. As the panel was unbalanced, this composition resulted in a maximum total of 2394 observations. The database included observations for the ROA, market-tobook ratio, and leverage. It was decided to remove the outliers in order to provide better estimates.

Regarding the performance measurement variables (ROA and market-to-book), which covered the period from 2010 to 2016, the results corroborate the findings of Sheikh and Wang (2013), in which, on average, Brazilian companies did not present expressive returns nor high expectations of future growth, as shown in Table 4.

For the variables that capture the structure of the companies of the sample, it was verified that the leverage of the companies present an average of 0.75 , that is, a high level of debt. With regard to internationalization, only $7 \%$ of the companies that make up the sample issue ADRs and, consequently, have extensive operations in international markets. The mean growth observed in the period was around 5.9\%, which shows a favorable scenario for the companies.

\subsection{Inferential analysis of the relationship between management practices and the performance of Brazilian companies}

This section presents the results of the analysis of the relationship between the GMAP guidelines and the organizational performance of Brazilian companies. This analysis was divided into two parts, according to the research hypotheses: the first concerns the companies' operational performance as represented by the ROA variable (Hypothesis 1) and the second concerns the market performance as represented by the market-to-book variable (Hypothesis 2).

The models were estimated by means of multiple regressions, using fixed effects and random effects methods, according to the specifications of the tests. The Chow test aimed to guide the choice between the pooled model and 
Table 4

Descriptive statistics of performance variables, Global Management Accounting Principles indexes, and control variables $(2010-2016)$

\begin{tabular}{cccccrrr}
\hline Variables & Obs. & Mean & Median & $\begin{array}{c}\text { Standard } \\
\text { Deviation }\end{array}$ & Minimum & Maximum \\
\hline ROA & 2267 & 0.020 & 0.052 & 0.324 & -5.230 & 0.697 \\
Market-to-Book & 2297 & 1.402 & 0.900 & 2.071 & -5.704 & 15.572 \\
Index & 2394 & 0.530 & 0.500 & 0.256 & 0.000 & 1.000 \\
Weighted Index & 2394 & 0.527 & 0.500 & 0.260 & 0.000 & 1.000 \\
PCA Index & 2394 & 0.000 & -0.193 & 1.000 & -1.499 & 2.762 \\
Size & 2343 & 21.160 & 21.523 & 2.678 & 6.507 & 27.968 \\
Internationalization & 2394 & 0.073 & 0.000 & 0.260 & 0.000 & 1.000 \\
Leverage & 2297 & 0.757 & 0.621 & 0.848 & 0.013 & 11.000 \\
Growth & 1960 & 0.059 & 0.084 & 0.540 & -7.047 & 5.883 \\
\hline
\end{tabular}

Note. ROA - Return on Assets. Source: Data from Thomson Reuters Eikon ${ }^{\mathrm{ma}}$ (2018).

fixed effects estimators. The Breusch-Pagan test aimed to guide the choice between the pooled model and random effects estimators. The Hausman test was used for guiding the choice between the fixed effects and random effects estimators.

Besides these tests, the Jarque Bera tests were used to estimate normality. It was noted that the data do not present a normal distribution. The VIF test for multicollinearity verified the absence of this problem in the set of variables analyzed. The White and Wald tests were performed and it was observed that the behavior of the variables is heteroscedastic. For autocorrelation, the Wooldridge test was used and showed that the data have first-order autocorrelation. To correct these problems, the models were estimated with the Driscoll and Kraay correction for standard errors of the coefficients estimated by fixed effects; and with cluster correction, which calculates the grouped errors for the models estimated by random effects.

\subsection{Results for operational performance}

As shown in Table 5, according to the $\mathrm{F}$ and $\mathrm{Chi}^{2}$ tests the models without controls were not significant. Therefore, the hypothesis that at least one variable contributes to explaining the model is not rejected; that is, the model is not adequate to provide reliable inferences about the relationship. However, the results of the $\mathrm{F}$ and $\mathrm{Chi}^{2}$ tests for the models with control variables were significant, so they can be considered adequate to explain performance measured by the ROA; however, they present a very low capacity to explain variations in organizational performance.
As also shown in Table 5, when the relationship between the managerial information indexes and operational performance was verified, it was initially perceived that when only the variable of interest and the dependent variable are considered, the relationship verified is negative, but not significant. However, as the control variables were added, this relationship was maintained and became statistically significant, suggesting the opposite of what was expected; that is, the more control companies have over their management practices, the greater their performance.

This result is also repeated for the sample that does not consider companies in the financial sector, but with statistical significance only for the model in which the index was measured using PCA. This result is the opposite of the one expected, since the higher the quality of an organization's controllership and/or management accounting, the higher its organizational performance. Thus, as proposed by the framework presented by the CGMA and the literature, strategy and planning are of great value to performance, as well as making it consistent over time (Carroll, 1982; CGMA, 2016).

One possible explanation would be that in some cases information on management practices may not be sufficiently clear and relevant to help in the financial decisions taken by companies in a timely manner. Management information may have a greater impact on non-financial performance measures, such as measures related to cost, innovation, or customer satisfaction (Neely, Gregory, \& Platts, 1995).

Corroborating this perspective, Ittner and Larcker (1998) and Simon et al. (2015) verified the impact of the 
Table 5

Determinants of company operating performance, measured by return on assets (2010 - 2016)

\begin{tabular}{|c|c|c|c|c|c|c|c|c|c|}
\hline \multirow[b]{2}{*}{ Variables } & \multicolumn{3}{|c|}{ No controls } & \multicolumn{2}{|c|}{ With controls } & \multicolumn{4}{|c|}{ No financial firms } \\
\hline & Index & $\begin{array}{l}\text { Weighted } \\
\text { Index }\end{array}$ & $\begin{array}{l}\text { PCA } \\
\text { Index }\end{array}$ & Index & $\begin{array}{l}\text { Weighted } \\
\text { Index }\end{array}$ & $\begin{array}{l}\text { PCA } \\
\text { Index }\end{array}$ & Index & $\begin{array}{l}\text { Weighted } \\
\text { Index }\end{array}$ & $\begin{array}{c}\text { PCA } \\
\text { Index }\end{array}$ \\
\hline \multirow[t]{2}{*}{ MPOI } & -0.032 & -0.031 & -0.006 & $-0.035^{* *}$ & $-0.035^{* *}$ & $-0.008^{* *}$ & -0.009 & -0.008 & $-0.008^{*}$ \\
\hline & $(0.028)$ & $(0.029)$ & $(0.005)$ & $(0.013)$ & $(0.014)$ & $(0.004)$ & $(0.019)$ & $(0.017)$ & $(0.004)$ \\
\hline \multirow[t]{2}{*}{ SIZE } & - & - & - & -0.005 & -0.005 & 0.002 & -0.012 & -0.012 & 0.004 \\
\hline & - & - & - & $(0.009)$ & $(0.009)$ & $(0.005)$ & $(0.013)$ & $(0.013)$ & $(0.005)$ \\
\hline \multirow{2}{*}{ LEV } & - & - & - & $-0.055^{* * *}$ & $-0.055^{* * *}$ & $-0.058^{* *}$ & $-0.057^{* * *}$ & $-0.057^{* * *}$ & $-0.057^{* * *}$ \\
\hline & - & - & - & $(0.013)$ & $(0.013)$ & $(0.028)$ & $(0.014)$ & $(0.014)$ & $(0.029)$ \\
\hline \multirow[t]{2}{*}{ G } & - & - & - & $0.034^{* * *}$ & $0.034^{* * *}$ & $0.034^{* * *}$ & $0.026^{* *}$ & $0.026^{* *}$ & $0.024^{* *}$ \\
\hline & - & - & - & $(0.009)$ & $(0.009)$ & $(0.010)$ & $(0.007)$ & $(0.007)$ & $(0.010)$ \\
\hline \multirow[t]{2}{*}{ INTER } & - & - & - & $0.046^{* *}$ & $0.047^{* *}$ & 0.014 & $0.044^{* *}$ & $0.044^{* *}$ & 0.012 \\
\hline & - & - & - & $(0.013)$ & $(0.013)$ & $(0.014)$ & $(0.013)$ & $(0.013)$ & $(0.016)$ \\
\hline \multirow[t]{2}{*}{ Constant } & 0.038 & 0.037 & 0.010 & 0.221 & 0.222 & 0.052 & 0.352 & 0.353 & 0.012 \\
\hline & $(0.020)$ & $(0.021)$ & $(0.017)$ & $(0.199)$ & $(0.197)$ & $(0.102)$ & $(0.280)$ & $(0.275)$ & $(0.117)$ \\
\hline $\mathrm{Chi}^{2} / \mathrm{F}$ Test & 1.330 & 1.150 & 1.290 & 133.890 & 153.360 & 28.790 & 18.730 & 20.440 & 22.960 \\
\hline $\mathrm{Chi}^{2} / \mathrm{F}$ (Prob) Test & 0.292 & 0.325 & 0.257 & 0.000 & 0.000 & 0.000 & 0.001 & 0.001 & 0.000 \\
\hline $\mathrm{R}^{2}$ Within & 0.000 & 0.000 & 0.000 & 0.085 & 0.085 & 0.087 & 0.077 & 0.077 & 0.077 \\
\hline $\mathrm{R}^{2}$ Between & 0.084 & 0.088 & 0.000 & 0.092 & 0.089 & 0.155 & 0.071 & 0.071 & 0.181 \\
\hline $\mathrm{R}^{2}$ Overall & 0.050 & 0.052 & 0.000 & 0.084 & 0.083 & 0.127 & 0.074 & 0.074 & 0.131 \\
\hline VIF & 1.000 & 1.000 & 1.000 & 1.670 & 1.690 & 1.290 & 1.940 & 1.980 & 1.400 \\
\hline Chow F & 0.000 & 0.000 & 0.000 & 0.000 & 0.000 & 0.000 & 0.000 & 0.000 & 0.000 \\
\hline Breusch-Pagan & 0.000 & 0.000 & 0.000 & 0.000 & 0.000 & 0.000 & 0.000 & 0.000 & 0.000 \\
\hline Hausman & 0.000 & 0.000 & 0.868 & 0.002 & 0.001 & 0.119 & 0.007 & 0.006 & 0.009 \\
\hline Model & $\begin{array}{l}\text { Robust } \\
\text { Fixed }\end{array}$ & $\begin{array}{l}\text { Robust } \\
\text { Fixed }\end{array}$ & Random & $\begin{array}{l}\text { Robust } \\
\text { Fixed }\end{array}$ & $\begin{array}{l}\text { Robust } \\
\text { Fixed }\end{array}$ & Random & $\begin{array}{l}\text { Robust } \\
\text { Fixed }\end{array}$ & $\begin{array}{l}\text { Robust } \\
\text { Fixed }\end{array}$ & Random \\
\hline Obs & 2267 & 2267 & 2267 & 1927 & 1927 & 1927 & 1637 & 1637 & 1637 \\
\hline
\end{tabular}

Notes. (1) Standard errors in parentheses. (2) ${ }^{\star \star \star},{ }^{* \star},{ }^{\star}$ Statistically significant at the $1 \%, 5 \%$, and $10 \%$ level, respectively. (3) Estimated standard errors with Wald and Wooldridge corrections for heteroscedasticity and autocorrelation, respectively. (4) According to the central limit theorem, the assumption of normality can be relaxed. Source: Data of the Thomson Reuters Eikon ${ }^{\mathrm{mm}}$ (2018).

quality of strategies on financial and non-financial measures, and obtained a positive and significant relationship. It was also noted that the impact on non-financial measures is greater than on the financial ones. The authors' explanation for this finding was that companies that are more concerned with quality and innovation-oriented strategies give more weight to non-financial performance, that is, customer satisfaction, employees, investors, quality of service or product, etc.

With respect to the other variables included in the model, company size presented a directly proportional relationship with performance, but without statistical significance both for the full sample and for the one without financial firms. This means that larger companies tend to have higher performance relative to other companies in the market. This result was the opposite of the ones found by Bomfim and Callado (2016b), Ribeiro, Alves, Taffarel, and Menon (2017), and Yound, Snell, Dean, and
Lepak, (1996), since their results showed that companies present lower rates of returns.

As expected, company growth had a positive and significant relationship with performance, thus corroborating the studies by Bol (2011) and Brito, Brito, and Morganti (2009). It was found that, just as in the literature, the company's growth rate changes according to changes in the organization's strategies or operational decisions (Cao \& Montezano, 2016).

The indebtedness variable obtained the relationship expected in the literature, that is, an inversely proportional and significant relationship with company performance, In other words, companies with a high degree of indebtedness tend to obtain lower returns on the capital invested in the organization. This result corroborates that of Bomfim and Callado (2016a) regarding indebtedness, in which an inverse relationship with company performance was also obtained. 
As for internationalization, as expected from the literature review, a directly proportional relationship was found, suggesting that companies with operations in other markets have higher organizational performance. This is the opposite result to that found by Andrade and Galina (2013), which showed a negative relationship between the company's performance and internationalization.

Therefore, based on the evidence indicated by the estimates, Hypothesis 1, which suggests that companies that comply more with GMAP guidelines have greater operational performance, is rejected. The result found was the opposite of what was expected and suggests that higher quality controllership results in lower company performance.

\subsubsection{Results for economic performance}

Regarding the relationship between the GMAP guidelines and company economic performance (Table 6), according to the $\mathrm{F}$ Test and $\mathrm{Chi}^{2}$, all models (except the model without controls using the PCA Index) were suitable for explaining the proposed relationship; that is, it is possible to make inferences with statistical significance. As for the $\mathrm{R}^{2}$ of the estimated models, there is a very low capacity to explain variations in expected growth measured by the market-to-book ratio.

Contrary to the results obtained for operating performance, the proposed models for economic performance showed a positive relationship for all models (with and without controls), with statistical significance for those estimated using the Index and the Weighted Index. Therefore, the evidence obtained is that higher quality management accounting increases companies' growth expectations, that is, it creates value for them.

These results are in line with what was expected in the literature, in which the use of better management

\section{Table 6}

Determinants of company economic performance, measured by the market-to-book ratio (2010 - 2016)

\begin{tabular}{|c|c|c|c|c|c|c|c|c|c|}
\hline \multirow[b]{2}{*}{ Variables } & \multicolumn{3}{|c|}{ No controls } & \multicolumn{3}{|c|}{ With controls } & \multicolumn{3}{|c|}{ No financial firms } \\
\hline & Index & $\begin{array}{l}\text { Weighted } \\
\text { Index }\end{array}$ & $\begin{array}{l}\text { PCA } \\
\text { Index }\end{array}$ & Index & $\begin{array}{l}\text { Weighted } \\
\text { Index }\end{array}$ & $\begin{array}{l}\text { PCA } \\
\text { Index }\end{array}$ & Index & $\begin{array}{l}\text { Weighted } \\
\text { Index }\end{array}$ & $\begin{array}{l}\text { PCA } \\
\text { Index }\end{array}$ \\
\hline \multirow[t]{2}{*}{ MPOI } & $1.043^{* *}$ & $1.016^{* *}$ & 0.051 & $0.967^{* *}$ & $0.877^{* *}$ & -0.012 & $1.220^{* * *}$ & $1.151^{* * *}$ & 0.037 \\
\hline & $(0.360)$ & $(0.320)$ & $(0.072)$ & $(0.330)$ & $(0.265)$ & $(0.050)$ & $(0.263)$ & $(0.181)$ & $(0.064)$ \\
\hline \multirow[t]{2}{*}{ SIZE } & - & - & - & $-0.413^{* *}$ & $-0.402^{* *}$ & $-0.323^{* *}$ & $-0.536^{* * *}$ & $-0.526^{* * *}$ & $-0.427^{* *}$ \\
\hline & - & - & - & $(0.135)$ & $(0.135)$ & $(0.124)$ & $(0.134)$ & $(0.133)$ & $(0.139)$ \\
\hline \multirow[t]{2}{*}{ LEV } & - & - & - & $-0.153^{* * *}$ & $-0.149^{* * *}$ & $-0.130^{* * *}$ & $-0.178^{* * *}$ & $-0.175^{* * *}$ & $-0.149^{* *}$ \\
\hline & - & - & - & $(0.035)$ & $(0.036)$ & $(0.032)$ & $(0.047)$ & $(0.048)$ & $(0.052)$ \\
\hline \multirow[t]{2}{*}{ G } & - & - & - & $0.221^{* * *}$ & $0.220^{* *}$ & $0.206^{* *}$ & $0.208^{* * *}$ & $0.208^{* * *}$ & $0.192^{* *}$ \\
\hline & - & - & - & $(0.060)$ & $(0.061)$ & $(0.063)$ & $(0.058)$ & $(0.058)$ & $(0.062)$ \\
\hline \multirow[t]{2}{*}{ INTER } & - & - & - & $0.497^{* * *}$ & $0.487^{* * *}$ & $0.549^{* * *}$ & $0.508^{* * *}$ & $0.492^{* * *}$ & $0.585^{* * *}$ \\
\hline & - & - & - & $(0.092)$ & $(0.095)$ & $(0.082)$ & $(0.089)$ & $(0.089)$ & $(0.082)$ \\
\hline \multirow[t]{2}{*}{ Constant } & $0.838^{* * *}$ & $0.856^{* * *}$ & $1.419^{* * *}$ & $9.903^{* * *}$ & $9.727^{* *}$ & $8.511^{* *}$ & $12.436^{* * *}$ & $12.280^{* * *}$ & $11.777^{* * *}$ \\
\hline & $(0.171)$ & $(0.148)$ & $(0.097)$ & $(2.765)$ & $(2.794)$ & $(2.264)$ & $(2.803)$ & $(2.817)$ & $(2.961)$ \\
\hline $\mathrm{Chi}^{2} / \mathrm{F}$ Test & 0.360 & 10.120 & 0.500 & 85.550 & 78.570 & 54.100 & 126.860 & 119.520 & 47.950 \\
\hline $\mathrm{Chi}^{2} / \mathrm{F}$ (Prob) Test & 0.028 & 0.019 & 0.478 & 0.000 & 0.000 & 0.000 & 0.000 & 0.000 & 0.000 \\
\hline $\mathrm{R}^{2}$ Within & 0.006 & 0.006 & 0.000 & 0.019 & 0.018 & 0.015 & 0.025 & 0.024 & 0.018 \\
\hline $\mathrm{R}^{2}$ Between & 0.096 & 0.099 & 0.012 & 0.004 & 0.004 & 0.017 & 0.017 & 0.017 & 0.036 \\
\hline $\mathrm{R}^{2}$ Overall & 0.063 & 0.064 & 0.005 & 0.000 & 0.000 & 0.004 & 0.002 & 0.002 & 0.010 \\
\hline VIF & 1.000 & 1.000 & 1.000 & 1.670 & 1.690 & 1.290 & 1.940 & 1.970 & 1.400 \\
\hline Chow F & 0.000 & 0.000 & 0.000 & 0.000 & 0.000 & 0.000 & 0.000 & 0.000 & 0.000 \\
\hline Breusch-Pagan & 0.000 & 0.000 & 0.000 & 0.000 & 0.000 & 0.000 & 0.000 & 0.000 & 0.000 \\
\hline Hausman & 0.008 & 0.006 & 0.089 & 0.000 & 0.002 & 0.000 & 0.000 & 0.000 & 0.000 \\
\hline \multirow[t]{2}{*}{ Model } & Fixed & Fixed & Random & Fixed & Fixed & Fixed & Fixed & Fixed & Fixed \\
\hline & Robust & Robust & & Robust & Robust & Robust & Robust & Robust & Robust \\
\hline Obs & 2297 & 2297 & 2297 & 1927 & 1927 & 1927 & 1628 & 1628 & 1628 \\
\hline
\end{tabular}

Notes. (1) Standard errors in parentheses. (2) ${ }^{* *},{ }^{* *},{ }^{\star}$ Statistically significant at the $1 \%, 5 \%$, and $10 \%$ level, respectively. (3) Estimated standard errors with Wald and Wooldridge corrections for heteroscedasticity and autocorrelation, respectively. (4) According to the central limit theorem, the assumption of normality can be relaxed. Source: Data from the Thomson Reuters Eikon ${ }^{\mathrm{Tm}}$ (2018). 
practices by companies would contribute to organizational performance, mainly in terms of value creation for stakeholders (CGMA, 2016). This finding corroborates the result found by Zott and Amit (2008), which showed that the construction of business model strategies affects the value creation of organizations. This evidence was obtained from 170 North American and European companies.

At this point, the results are consistent with institutional theory, since the organizational identity of the companies is built and shaped based on adopted routines and patterns, seeking more efficient process management (Guerreiro et al. 2005; Scapens, 1994). Managerial accounting is one of these routines and the management principles are a way to shape and improve them and, consequently, generate more value for the companies, as shown in Table 6.

Regarding the other control variables, company size showed an inverse relationship with value creation, which was significant in both the complete sample and the sample without financial companies. This result suggests that, as they already cover a large part of the market, bigger companies have lower growth capacity compared to smaller ones that have a larger field for expansion. In that sense, the expectations of future growth and value creation by these companies are lower. This result corroborates the one found by Youndt et al. (1996).

Company leverage has the expected relationship, with a negative and significant sign, as shown in Table 5. This reflects the propensity of greater indebtedness to increase company risks, where, consequently, its own capital cost will impact company performance and value creation. These findings are consistent with those evidenced by Sheikh and Wang (2013) in the Pakistani market for the relationship between capital structure and the performance of non-financial corporations.

Similarly to the ROA result, growth and internationalization also have a positive and significant relationship, as expected. These findings are consistent with those of Bol (2011), Brito, Brito, and Morganti (2009), and Sheikh and Wang (2013), in which companies with greater growth and expansion in other markets have higher value creation.

Thus, the proposed estimates provide evidence that supports the non-rejection of Hypothesis 2, which foresaw a positive relationship between Global Management Accounting Principles and value creation by organizations. That is, the use of more appropriate management accounting practices that seek to improve the management of available resources, integrating all parts of the organization, contributes to the value creation of organizations.

In general, the findings of the study emphasize the importance of pursuing best management practices, that is, making use of conduits and instruments that promote organizational efficiency and effectiveness and enable companies to remain competitive in the market.

\section{Final Considerations}

Considering the importance of management accounting in organizational decisions, together with the structure proposed by the CGMA, the research problem focused on the relationship between Brazilian companies' management practices and their organizational performance.

First, the index based on management information presented in the reports released by the companies showed that they adopt about $53 \%$ of the practices that are considered important for management. This result was positive, with a growing percentage in recent years, reaching a rate of $57 \%$ in 2016 . In this sense, these managerial practices can be viewed as a routine by companies, mainly due to the fact that the index presents few variations. This result fits into the perspective of institutional theory, which sees a management system as an important organizational routine (Scapens, 1994). But it also tells us that there is fear on the part of organizations to disclose managerial matters. This may be explained by the fear of providing their competitors with some competitive advantage. It may even be an indication of companies' attempts to hide the inefficiency of their managers (Aillón et al., 2013).

Regarding the results found for organizational performance, observed within the operational sphere, a negative relationship was obtained between the use of good management practices and company performance. This finding is the opposite of what was expected, since the literature suggests that the function of management accounting is to provide strategies that can assist in organizational growth (CGMA, 2016). For the market sphere, the relationship obtained was positive and significant, therefore affirming what is proposed by the CGMA structure, in which the management practices of organizations are fundamental to company value creation. 
Contributions of the study include the evidence obtained in relation to management principles, as a set of measures capable of assisting companies in their decision making, particularly in combination with management practices that affect the performance of the companies studied.

It should be noted that the study's results may have been affected by the limitations inherent to the subjectivity in the interpretations, which largely depend on the researcher's judgment capacity. Importantly, these results should not be generalized due to the limited sample period and because it only includes Brazilian companies. For future studies, we suggest extending the sample period to verify the relationship between the GMAP and organizational performance, as well as using other methodologies to measure managerial information, such as questionnaires or interviews, to verify the quality of the management systems and identify the main factors that impact these systems.

\section{References}

Aillón, H. S., Silva, J. O., Pinzan, A. F., \& Wuerges, A. F. E. (2013). Análise das informações por segmento: Divulgação de informações gerenciais pelas empresas brasileiras. Revista Contemporânea de Contabilidade, 10(19), 33-48.

Almatrooshi, B., Singh, S. K., \& Farouk, S. (2016). Determinants of organizational performance: A proposed framework. International Journal of Productivity and Performance Management, 65(6), 844-859.

Andrade, A. M. F., \& Galina, S. V. R. (2013). Efeitos da internacionalização sobre o desempenho de multinacionais de economias em desenvolvimento. Revista de Administração Contemporânea, 17(2), 239-262.

Assaf, A., Neto. (2014). Finanças Corporativas e Valor (7th ed.). São Paulo: Atlas.

Bol, J. C. (2011). The determinants and performance effects of managers' performance evaluation biases. Accounting Review, 86(5), 1549-1575.

Bomfim, E. T., \& Callado, A. L. C. (2016a). Análise do desempenho econômico-financeiro de empresas brasileiras que realizaram operaçóes de fusóes e de aquisiçóes. Revista de Ciências da Administração, 18(45), 79-95.

Bomfim, E. T., \& Callado, A. L. C. (2016b). Análise dos efeitos provocados pelas operações de fusôes e aquisiçóes no desempenho econômico-financeiro de empresas brasileiras. Revista Contabilidade Vista e Revista, 27(83), 105-123.

Borker, D. R. (2016a). Gauging the impact of countryspecific values on the acceptability of global management accounting principles. European Research Studies, 19(1), 149-164.

Borker, D. R. (2016b). Global management accounting principles and the worldwide proliferation of IFRS. The Business and Management Review, 7(3), 258-267.

Brito, E. P. Z., Brito, L. A. L., \& Morganti, F. (2009). Inovação e o desempenho empresarial: Lucro ou crescimento? Revista de Administração de Empresas, 8(1).

Burns, J., \& Scapens, R. W. (2000). Conceptualizing management accounting change: An institutional framework. Management Accounting Research, 11(1), 3-25.

Cao, T. R., \& Montezano, R. M. S. (2016). Initial public offering and performance of brazilian firms. Revista de Gestão, Finanças e Contabilidade, 6(2), 160-178.

Carroll, P. J. (1982). The link between performance and strategy. The Journal of Business Strategy, 2(4), 3-20.

Chartered Global Management Accountant. (2016). Princípios globais de contabilidade gerencial: Contabilidade gerencial eficaz: Melhorando as decisóes e construindo organizaçôes de sucesso (L. Roberval Vieira Goes, Trad.). Nova York: AICPA; CIMA.

Feldmann, P. R., Jacomossi, R. R., Barrichello, A., \& Morano, R. S. (2019). A relação entre a inovação e a competitividade global: O papel mediador das práticas de gestâo avaliadas pela equação estrutural. Revista Brasileira de Gestão de Negócios, 21(2), 195-212.

Frezatti, F., Bido, D. S., Cruz, A. P. C., \& Machado, M. J. C. (2015). A estrutura de artefatos de controle gerencial no processo de inovação: Existe associação com o perfil estratégico? Brazilian Business Review, 12(1), 129-156. 
Frezatti, F., Aguiar, A. B., \& Guerreiro, R. (2007). Diferenciações entre a contabilidade financeira e a contabilidade gerencial: Uma pesquisa empírica a partir de pesquisadores de vários países. Revista Contabilidade \& Finanças, 18(44), 9-22.

Guerreiro, R., Frezatti, F., Lopes, A. B., \& Pereira, C. A. (2005). O entendimento da contabilidade gerencial sob a ótica da teoria institucional. Revista Organizaçóes \& Sociedades, 12(35), 91-106.

Ittner, C. D., \& Larcker, D. F. (1998). Are non-financial measures leading indicators of financial performance? An analysis of customer satisfaction. Journal of Accounting Research, 36(3), 1-35.

Ittner, C. D, Larcker, D. F, \& Rajan, M. V. (1997). The choice measures bonus of in performance annual contracts. The Accounting Review, 72(2), 231-255.

Kaplan, R. S. (1984). The evolution of management accounting. The Accounting Review, 59(3), 390-418.

Konsta, K., \& Plomaritou, E. (2012). Key performance indicators (KPIs) and shipping companies performance evaluation: The case of Greek tanker shipping companies. International Journal of Business and Management, 7(10), 142-155.

Lima, E. M., Espejo, M. B., Pereira, C. A., \& Frezatti, F. (2011). As respostas do GECON às críticas do relevance lost. Revista Contabilidade Vista Revista, 22(11), 177-200.

Maroco, J. (2003). Análise estatística com utilizaçāo do SPSS (2nd ed.). Lisboa: Sílabo.

Masztalerz, M. (2014). Global management accounting principles: Emperor's new clothes? Performance Measurement and Management, 345, 57-65.

Masztalerz, M. (2016). Why narratives in accounting? Quantitative Methods in Accounting and Finance, 423, 99-107.

Neely, A., Gregory, M., \& Platts, K. (1995). Performance measurement system design: A literature review and research agenda. International Journal of Operations \& Production Management, 15(4), 80-116.
Petrini, M., Scherer, P., \& Back, L. (2016). Modelo de negocios com impacto social. Revista de Administração de Empresas, 56(2), 209-225.

Pontiff, J., \& Schall, L. D. (1998). Book-to-market ratios as predictors of market returns. Journal of Financial Economics, 49(2), 141-160.

Ribeiro, F., Alves, T. A., Taffarel, M., \& Menon, G. (2017). Responsabilidade social corporativa e o desempenho financeiro no setor de energia elétrica: Um estudo com modelo de dados em painéis. Gestão \& Regionalidade, 33(99).

Scapens, R. W. (1994). Never mind the gap: Towards an institutional perspective on management accounting practice. Management Accounting Research, 5(3-4).

Sheikh, N., \& Wang, Z. (2013). The impact of capital structure on performance. International Journal of Commerce and Management, 23(4), 354-368.

Simon, A., Bartle, C., Stockport, G., Smith, B., Klobas, J. E., \& Sohal, A. (2015). Business leaders' views on the importance of strategic and dynamic capabilities for successful financial and non-financial business performance. International Journal of Productivity and Performance Management, 64(7), 908-931.

Simons, R. (1995). Levers of control: How managers use innovative control systems to drive strategic renewal. Boston: Harvard Business Press.

Souza, M. A., Lisboa, L. P., \& Rocha, W. (2004). Práticas de contabilidade gerencial adotadas por subsidiárias brasileiras de empresas multinacionais. BASE-Revista de Administração e Contabilidade da Unisinos, 1(1), 47-60.

Takeda, H., \& Boyns, T. (2014). Management, accounting and philosophy. Accounting, Auditing \& Accountability Journal, 27(2), 317-356.

Yazdifar, H., \& Tsamenyi, M. (2005). Management accounting change and the changing roles of management accountants: A comparative analysis between dependent and independent organizations. Journal of Accounting \& Organizational Change, 1(2), 180-198. 
Youndt, M. A., Snell, S. A., Dean, J W., .Jr. \& Lepak, D. P. (1996). Human resource management, manufacturing strategy, and firm performance. Academy of Management Journal, 39(4), 836-866.

Zhu, Q., \& Sarkis, J. (2004). Relationships between operational practices and performance among early adopters of green supply chain management practices in Chinese manufacturing enterprises. Journal of Operations Management, 22(3), 265-289.

Zott, C., \& Amit, R. (2008). The fit between product market strategy and business model: Implications for firm performance. Strategic Management Journal, 29, 1-26. 
Ingrid Costa / Wenner Lucena

\section{Financial support:}

Name of the funding agency /OR/ There are no funding agencies to report.

\section{Conflicts of interest:}

The authors have no conflict of interest to declare.

\section{Copyrights:}

RBGN owns the copyrights of this published content.

\section{Plagiarism analysis:}

RBGN performs plagiarism analysis on all its articles at the time of submission and after approval of the manuscript using the iThenticate tool.

\section{Authors:}

1. Ingrid Laís de Sena Costa, Master, Federal University of Tocantins, Palmas, Brazil.

Federal University of Paraíba, João Pessoa, Brazil.

Email: ilsenna2.0@gmail.com

2. Wenner Glaucio Lopes Lucena, PhD, Federal University of Paraíba, João Pessoa, Brazil.

Email:wdlucena@yahoo.com.br

\section{Authors' Contributions:}

$\mathbf{1}^{\text {st }}$ author: Definition of research problem; Development of hypotheses or research questions (empirical studies);

Development of theoretical propositions (theoretical work); Definition of methodological procedures; Data Collection; Literature review; Statistical analysis; Analysis and interpretation of data; Critical revision of the manuscript; Manuscript writing.

$2^{\text {nd }}$ author: Definition of research problem; Development of hypotheses or research questions (empirical studies);

Development of theoretical propositions (theoretical work); Definition of methodological procedures; Literature review;

Statistical analysis; Analysis and interpretation of data; Critical revision of the manuscript; Manuscript writing. 